\title{
Handout or hand-up: Ongoing tensions in the long history of government response to drought in Australia
}

\author{
Karen Downing, Rebecca Jones, Blake Singley* \\ School of History, Research School of Social Sciences, The Australian National University
}

\begin{abstract}
In 2014 the Coalition government announced a 320 million dollar package for drought-hit farmers. In describing this initiative as a 'hand-up' not a 'hand out' Prime Minister Tony Abbott encapsulated more than 150 years of tension over whether government drought response should be unconditional limited relief or conditional longer-term assistance. This paper considers the long history of drought assistance in Australia as seen through government legislation, year books, newspapers and personal papers. It argues that despite changing political and social circumstances, contradictions in the approach to government drought response, as well as in public and personal reactions to those policies, have remained remarkably consistent. We further suggest that lack of consensus over the inherent nature of drought is not sufficient to explain the dilemma.
\end{abstract}

\section{Introduction}

In February 2014 the Tony Abbott-led Coalition government announced a $\$ 320$ million package for drought-hit farmers in Queensland and New South Wales. "This is not a handout as such", said Prime Minister Abbott. "It is a hand-up so it is rather different from previous drought assistance that has been offered by the Commonwealth." interest groups, affected farmers and media commentators, and the online public response to these opinions, included both praise for, and objection to, those parts of the package seen as a "handout", and criticism that the "hand-up" was not going to achieve longer term objectives for drought preparedness.

As this article will show, Abbott's attempt to distinguish "handouts" from "hand-ups" encapsulates an enduring dilemma for Australian governments over whether their response to the effects of drought should take the form of unconditional limited relief or conditional longerterm assistance. This article will also show that Abbott's claim that his government's approach was "rather different" from previous Commonwealth, or indeed state, assistance is unsupported. We argue that both "handouts" and "hand-ups" were evident in government drought funding throughout the late nineteenth and twentieth centuries. Moreover, public and individual farmers' responses to drought funding expressed similar criticism of, and confusion over, the purpose of government assistance as responses to the recent package. Part of the confusion is that limited

\footnotetext{
* The authors thank Professor Nicholas Brown and two anonymous reviewers for their constructive comments on drafts of this article. This research was supported by an Australian Research Council Discovery Early Career Researcher Award DE120100786 for Rebecca Jones and funds under an Australian National University College of Arts and Social Sciences Small Grant Scheme for Karen Downing.

1 "Drought Package: \$320 Million in Funding for NSW and Queensland Farmers", ABC News, 26 February 2014

< bttp:/ / wnw.abc.net.au/news/2014-02-26/300-million-drought-package-for-farmers/5284758>.
} 
welfare style payments in times of crisis (handouts) imply and support the idea that drought is an occasional abnormal crisis while finance for longer term structural reforms (hand-ups) ask farmers to adjust and prepare for the expected recurrence of drought. We suggest, however, that lack of consensus over the inherent nature of drought is not sufficient to explain the dilemma.

Farmers and agricultural communities have received drought assistance in many forms including charitable relief, public subscription and local fundraising. For the purposes of this article, we concentrate on government originated assistance at both a federal and state/colony level.

Previous studies of government drought assistance identify a "watershed" period in government responses to drought in the late 1980s to early 1990s. O'Meagher, du Pisani and White, writing in the 1990s prior to the drought of the 2000s, argue that there had been a fundamental shift in the approach of drought policy from compensation for adverse financial situations towards an emphasis on restructuring for self-reliance. In the context of their survey of post Second World War drought policies they identify this shift as occurring in the 1970s to 1980s. Linda Botterill identifies a similar trend in drought policy during the past 50 years. She argues that the removal of drought from Commonwealth and State natural disaster relief arrangements signalled a fundamental shift in government approaches which reshaped the focus of response from natural disaster relief to managing business risk. She dates this "watershed" decision to 1989. R. L. Heathcote traces a similar trajectory in his consideration of the past, present and future of drought management strategies. ${ }^{2}$

Policy of the late 1980s and early 1990s did signal a shift in recent government drought response, however, as Deb Anderson notes briefly in her discussion of drought narratives, the segregation of this paradigm shift is too tidy and differing discourses co-exist. ${ }^{3}$ The neat view of government drought response in Australia is not, we argue, a misinterpretation, rather it is the result of scholars focusing on "recent history" and on discrete drought policy as opposed to the many and varied government responses to the consequences of drought. The future-oriented, policyrelated research of Botterill, O'Meagher et. al., Heathcote and others, is driven by the very real, and very pressing, need for practical changes. In contrast to this previous research, our study of various government responses to drought, and public and personal attitudes to those responses, over the last 100 to 150 years shows that approaches to drought have only been consistent in their inconsistency. Rather than a trajectory that moves from treating drought as natural disaster to seeing it as part of "normal" farming business, from relief to restructuring, this longer-

\footnotetext{
2 B. O’Meagher, L.G. du Pisani and D.H. White, "Evolution of Drought Policy and Related Science in Australia and South Africa", Agricultural Systems, Vol. 57, 3 (1998), pp.231-58; R.L. Heathcote, Braving the Bull of Heaven: Drought Management Strategies, Past Present and Future (Milton, Qld., 2002); Linda Courtenay Botterill, "Uncertain Climate: The Recent History of Drought Policy in Australia", Australian Journal of Politics and History, Vol. 49, 1 (2003), pp.61-74; L.C. Botterill and B. Chapman, "Developing Equitable and Affordable Government Responses to Drought in Australia", Refereed paper presented to the Jubilee conference of the Australasian Political Studies Association (Canberra, 2002). ${ }^{3}$ Deb Anderson, Endurance: Australian Stories of Drought (Melbourne, 2014), p.32.

${ }^{4}$ Botterill, "Uncertain Climate", p.62.
} 
term investigation of drought assistance shows that both approaches have been a part of government response throughout the period covered. During this time both state and federal governments' drought responses have included both reactive compensation in the face of adverse financial circumstances and assistance directed at restructuring and refocussing agricultural practice - and public and private reactions have been as ambivalent in the past as they have been to the 2014 package of measures.

To achieve a long term perspective we have examined government responses to drought from the 1890s until today, a period of nearly 130 years. Although we have also examined documents mentioning drought in Historical Records Australia going back to 1788, the focus of our attention has been from the 1890s to the present. The Federation drought (1895-1903) marked a particularly significant chapter in Australian response to drought. This drought was the longest and most widespread since agriculture became established in south-eastern Australia and it starkly revealed the ambivalent responses to drought. Its impact was so severe that it became the benchmark against which all other droughts were compared for the next 100 years. Tom Griffiths has argued that this drought marked the beginning of a realisation that humans were agents in drought - that water and land management practices were, at least to some extent, responsible for the impact of drought. ${ }^{5}$ We feel, therefore, that the 1890 s is a significant starting point for our analysis of drought response.

In the period since the 1890 s there have been at least 10 severe droughts in south-eastern Australia, which is our geographical focus, the most serious and widespread of these being: 1895-1903; 1914-15; the late 1920s; 1938-45; the late 1960s; 1982-2; 1990s-2000s. We have concentrated on south-eastern Australia as, in a global context, it has an exceptionally variable climate influenced by its latitude, large continental mass and fluctuations in both the Pacific and Indian Oceans and is, therefore, particularly drought prone. ${ }^{6}$ Yet it is also very agriculturally productive with dairy, horticulture, broadacre cropping and pastoral activities. The limit to our geographical focus has determined our use of sources: Commonwealth, Victoria and New South Wales year books and legislation; selected newspapers; and personal documents of farmers in the two states. While acknowledging the specificities of place we have no reason to believe that the thrust of our argument would not hold for other parts of Australia.

For this historical rather than policy analysis we have integrated a diversity of sources. We have used the year books and legislation to summarise more than 100 years of government response to the effects of drought. We have examined newspapers to explore popular reactions to these

\footnotetext{
${ }^{5}$ Tom Griffiths, "The Nature of Culture and the Culture of Nature", in Cultural History in Australia, ed. Hsu-Ming Teo and Richard White (Sydney, 2003), p.78.

${ }^{6}$ Paul Holper and CSIRO, Climate Change Science Information Paper: Australian Rainfall: Past, Present and Future (Melbourne, 2011), pp.1-4.
} 
official measures and we have used personal stories of drought-affected farmers to give a more intimate picture of individual responses to drought assistance and the effect that assistance had on peoples' lives. For this research, each of these types of sources has advantages and disadvantages. Government documents show intent and allow generalisations to be made but fail to reveal the reaction or effect. The media, by contrast, suggests popular reactions but this may reinforce stereotypical rather than representative narratives. Diaries illustrate intimate and individual lived experience but unlike the other sources fail to reveal the broader picture. Together, however, these sources can allow complementary expressions to form an evocative whole.

The broad-brush approach of this article does not allow for a detailed political or social history but some of the major political and social influences on changing agricultural policy should be noted. Over the period of this study Australia has seen an increase in agricultural productivity at an individual farm level due largely to changing technology and agricultural practices and the availability of new varieties of plant and animal species. There has also been a decline in the real and proportional number of people directly engaged in agriculture and, as a result, a decline in the importance of the agricultural lobby in politics. Increases in real wages in Australia have arguably shifted the emphasis in agricultural production away from human labour towards technological labour. And, although wool and wheat production in Australia has, since the nineteenth century, been driven by international trade, chiefly with Britain, there has been a broader globalisation of Australia's economy in the last one hundred years. Coterminous with these moves have been increases in the provision of government welfare payments from the midtwentieth century, the influence of an ideology of economic rationalism with its focus on efficiency and individual achievement, and the emergence of an awareness of the environmental impact of some agricultural practices.

Continued contradictions in government responses to drought despite these changing political and social circumstances can be explained, in part, by tensions in the broader cultural understandings of drought in Australia since European settlement. Two principle conflicting narratives of drought are evident in the histories of climate response in Australia. The first is that drought is perceived as an aberration; that "normal" climate is predictable and consistent in its rainfall. The second is that drought is an inherent part of the Australian climate. As many historians and social commentators have noted, probably beginning with T. M. Perry in 1966, the first, more optimistic, view accompanied settlers from the British Isles and other parts of northern Europe whose skills, knowledge and technology were developed in lands where drought was not unknown, but was an unusual event. That Australia had a normally reliable rainfall was a belief clung to desperately by government, farmers and industrialists in the nineteenth century who wanted to expand agriculture and British immigration and provide British industry with a 
continuous supply of commodities. ${ }^{7}$ And yet this understanding of drought was not the only narrative of drought amongst settlers and governments through the nineteenth and twentieth centuries. Recurrent (although unpredictable) experiences of drought through the nineteenth and twentieth centuries challenged the belief in reliable rainfall. As Don Garden explains, the acceptance of drought as an inherent part of the Australian climate is evident in the development of large-scale irrigation as well as stock and domestic water schemes in New South Wales and Victoria following the federation drought ${ }^{8}$. Similarly, as Tom Griffiths and Deb Anderson show acceptance of the recurrence of drought is suggested in the prominent role which drought endurance plays in regional and national identity. ${ }^{9}$ As we explore below, these conflicting cultural understandings are both reflected in, and in turn, reproduced and reinforced by government policy.

Our discussion begins with an outline of the various features of government drought assistance over the long term that include both handouts and hand-ups though these are not always neatly distinguishable. We then move to the Advances to Settlers Act in New South Wales, enacted in 1899 and used continuously into the 1980s, as an example of the way in which drought has been treated as only one of the reasons for which farmers need support. We next take a closer look at the public and personal responses to government assistance during one particular drought, in 1914-15. We finish with a consideration of the idea of foresight and self-reliance which was seen to be a defining feature of the 1993 National Drought Policy but which, we argue, had been part of the debate about drought planning, recovery and support through the late nineteenth and early twentieth centuries. This historical perspective shows that a messy mix of approaches within government drought response, and ambivalence in public and personal reactions to these responses, has remained consistent for over 100 years. It also suggests that although better understanding of drought is necessary for achieving more effective policy approaches it may not be sufficient.

\section{A mix of government approaches}

Direct relief to farmers, which implied that drought was an unusual event for which farmers were to be compensated, were given in the form of seed advances, fodder, and freight assistance for stock and feed, though these were rarely direct "hand-outs". Recipients of an advance under the

\footnotetext{
7 Tom Griffiths, "One Hundred Years of Environmental Crisis", Rangelands Journal, Vol. 23, 1 (2001), pp.5-14. Don Garden, "Extreme Weather and ENSO: Their Social and Cultural Ramifications in New Zealand and Australia in the 1890s" in Climate, Science and Colonisation: Histories from Australia and New Zealand, ed. J. Beattie, E. O'Gorman and M. Henry (New York, 2014), pp.61-80; T.M. Perry, "Climate and Settlement in Australia 1700-1930", in Frontiers and Men, ed. J. Andrews (Melbourne, 1966), pp.138-54; R.L. Heathcote, "Drought in Australia: A Problem of Perception”, The Geographical Review, Vol. 59, 2 (1969), pp.175-94.

8 Garden, "Extreme Weather and ENSO", pp.74-77.

${ }^{9}$ Tom Griffiths, "The Nature of Culture and the Culture of Nature"; Deb Anderson, Endurance: Australian Stories of Drought.
} 
Victorian Seed Advances Act 1896 had a lien over their forthcoming crop until the advance was repaid with interest. ${ }^{10}$ The Act did not specifically mention drought as a condition under which advances would be paid but financial reports in Victorian Year Books show significant spikes in these advances during the drought years of 1902-03 and 1925-29.11

Subsidies might be considered more of a "hand-out", and these have been a recurrent feature of government response to drought. The New South Wales Government introduced "starving stock rates" on railways in 1898-99 which substantially reduced charges for moving stock to feed and water and moving fodder to drought areas. ${ }^{12}$ The Victorian government reimbursed their railways for the carriage of water in the same period and freight subsidies were also approved as late as 1977.13 Commonwealth Year Books noted frequent recourse to transport subsidies in this later period: with Victorian fodder shipped to New South Wales in 1965; freight concessions for drought relief in the Northern Territory from at least 1965 to 1970; and as part of the continuation of Commonwealth Government drought relief measures in New South Wales, South Australia and Western Australia in 1977.14 The Victorian Government also reported a Commonwealth grant for drought fodder subsidy in their financial reports between 1981 and 1984.15

While assistance in the form of subsidies is clearly related directly to the consequences of drought, far more of the assistance offered to farmers covered a range of perceived needs and obstacles to productivity of which drought was only one. This assistance was usually in the form of an advance which was expected to be repaid and could, therefore, be considered a "hand-up". Advances to farmers in 1896 were made from funds raised from the sale of mortgage bonds. Support offered under the Cultivation Advances Act 1927 was in the form of interest bearing loans for seed, fodder, manure, building and fencing materials, as well as money. ${ }^{16}$ The 1930 s Farmers Advances Act provided for interest bearing loans to farmers for the purchase of livestock, farm implements and machinery, as well as wages that the Commission found essential for farming operations and a sufficient living allowance for the farmer and his family. In the 1940s the same

\footnotetext{
10 Victorian Government Gazette, 13 March 1896

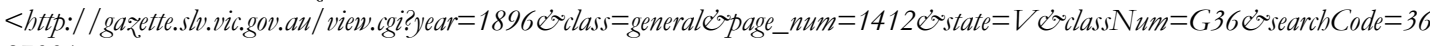
$27001>$.

11 Seed Advances Act 1896 <http:// wnw.austlii.edu.au/au/legis/vic/ hist_act/saa1896111.pdf >; Victorian Year Book (VYB) 1902-1903 and 1925-1929. This and all following Year Books available at Australian Bureau of Statistics Historical Publications Online (ABS)

<http:/ / wnw.abs.gov.au/ websitedbs/D3310114.nsf/4a256353001af3ed4b2562bb00121564/ 1c25c0499720503fca25757100198 73f! OpenDocument>.

${ }_{12}$ New South Wales Year Book (NSWYB), 1904-05, p.138.

13 NSWYB 1903: 153; NSWYB 1977, p.968.

${ }^{14}$ Commonwealth Year Book (CYB) 1965, p.1278; CYB 1971: 538; CYB 1977-78, p.756.

15 VYB 1982-1985.

16 VYB 1916-1917, p.409; Cultivation Advances Act 1927. This and all other legislation available at Australasian Legal Information Institute <http:/ / wmw.austlii.edu.au>.
} 
Act allowed for advances made between July 1944 and June 1945 to be interest free for three years to relieve conditions due to drought. ${ }^{17}$

This emphasis on access to financial credit for both short-term relief and long-term development continued in the second half of the twentieth century. The Farm Development Loan Fund was established in 1966 to provide loans to primary producers, at preferential rates and conditions, for drought relief and farm development purposes. During 1969, the Fund was used to provide longer term loans than were available on normal overdraft, the Year Book noting that this was for "drought prevention measures" as well as "developmental and export yielding projects". ${ }^{18}$ The 1982 Victorian Year Book noted the variety of sources of finance then available to the rural sector: the Rural Credits Department of the Reserve Bank advanced payments to growers of produce pending its sale; the Commonwealth Development Bank provided rural loans for farm improvement purposes; the Farm Development Loan Fund of the trading banks and the State Bank provided all-purpose loans; pastoral finance companies provide a variety of credit facilities to farmers "to cover all aspects of farm activity"; and additional finance was made available by the Primary Industry Bank of Australia Ltd to approved lending institutions for on-lending to the rural community to assist with refinancing arrangements. ${ }^{19}$

Schemes initiated by the Departments of Lands and Agriculture in New South Wales between 1915 and 1919 had also declared the dual purpose of assisting farmers "to cultivate new areas and to relieve necessitous farmers". ${ }^{20}$ Similarly, the Rural Industries Board, formed in 1919, had extended "the scope of relief given to necessitous farmers" while the primary objective of the Rural Bank, established in 1921, was to promote rural settlement and development. ${ }^{21}$ When assistance at this time was specifically to ameliorate the effects of drought it was in the form of commodities like fodder, seed wheat, fertiliser, tractor fuel, household supplies, and so on, and payment was made direct to suppliers. ${ }^{22}$

From the Seed Advances Act in 1896 and the Advances to Settlers Act 1899 to the Rural Credit and Community Settlement Scheme in the 1920s, the Farmers Advances Acts of the 1930s and Rural Reconstruction Scheme of the 1970s, drought was considered as just one of the circumstances which made farmers eligible for receipt of credit. Even when support was specifically described as "relief", such as in the Farmers Relief Acts of the $1930 \mathrm{~s}^{23}$ and the Drought Relief Acts of the 1940s to $1960 \mathrm{~s}^{24}$, financial assistance was mainly in the form of loans, so despite the tolerable terms, not

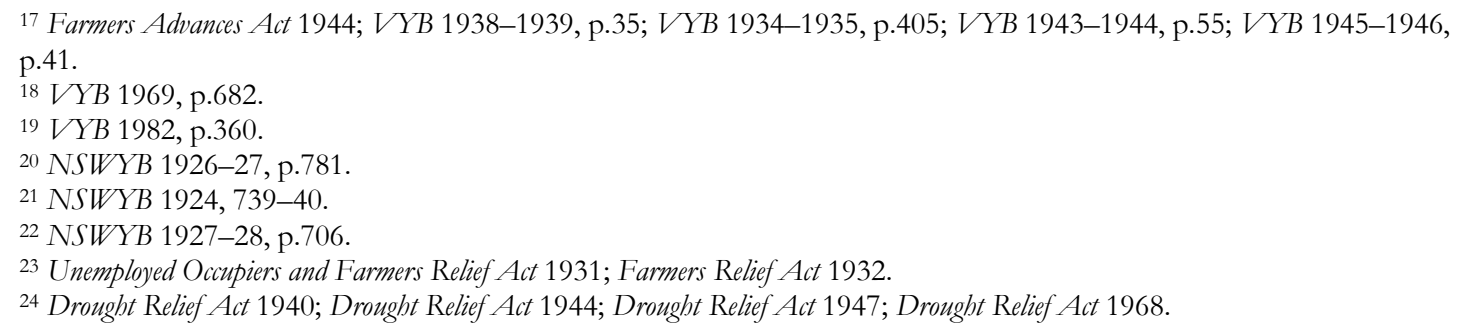


strictly a "hand-out". Moreover, the viability of the farm - an expectation that a "hand-up" would be worthwhile - was often a consideration in assessment of applications: a farmer applying under the Farmers Relief Act 1933, for example, needed to produce "satisfactory evidence" that "he [was] working his farm to its full capacity or that his failure to do so [was] the direct result of his financial position". ${ }^{25}$

Governments' use of taxation displayed a similarly variable approach. Taxation was initially used as a measure to alleviate the effects of drought but, later in the twentieth century, it was also used to provide incentive to prepare for drought. Amendments in 1914 to the Land Tax Assessment Act 1910-1912 named "drought" as a specific instance of "hardship"26 and the same amendment was made to the Income Tax Act in 1918. ${ }^{27}$ In 1995 changes in the Taxation Laws Amendment (Drought ReliefMeasures) Act provided a tax incentive, in the form of an allowable deduction, to encourage primary producers to invest in drought mitigation and referred to it as a "drought investment allowance". ${ }^{28}$ An earlier iteration of the current Farm Management Deposits Scheme was the 1968 Drought Bond Scheme which carried taxation concessions for primary producers and under which bonds could be prematurely redeemed to reduce the impact of drought, fire or flood. ${ }^{29}$ Tax concessions, tax remissions and tax incentives all remain part of current Commonwealth response to drought. ${ }^{30}$

The notion that farmers actually receive "handouts" for drought probably arises from the inclusion of drought relief under welfare services in the 1960s, with drought relief expenditure no longer reported in "assistance to primary producers, subsidies and bounties" but in "cash benefits to persons" as "special relief". ${ }^{31}$ The simultaneous use of taxation measures to provide relief and encourage preparedness is another example of government inability to resolve whether "handouts" or "hand-ups" are the appropriate response to drought.

\section{Advances to Settlers Act}

At the end of the nineteenth century money rather than climate was behind the views of New South Wales Government policy makers who believed that lack of capital prevented settlers from purchasing land outright from the Crown, obstructed the effective development of rural

\footnotetext{
${ }^{25}$ Farmers Relief Act 1933; VYB 1933-1934, p.417.

${ }^{26}$ Land Tax Assessment Act 1914.

27 Income Tax Act 1918.

${ }_{28}^{8}$ Taxation Laws Amendment (Drought Relief Measures) Act 1995.

${ }^{29}$ Department of Agriculture, "Enhancements to the Farm Management Deposits (FMD) Scheme", 15 May 2014 <http:/ / wnw.daff.gov.au/ agriculture-food/ drought/ assistance/fmd>, accessed 10/2/2015; CYB 1969, p.1248; CYB 1970, p.80; CYB 1970, p.1080; CYB 1971, p.581; CYB 1971, p.1055.

${ }^{30}$ Department of Agriculture, "Assistance Measures" < http:/ / www.daff.gov.au/ agriculture-food/drought/ assistance >, accessed $10 / 2 / 2015$

${ }_{31}$ CYB 1966, p.760.
} 
properties, and prevented farmers from riding out the tough times such as drought periods. ${ }^{32}$ In New South Wales this capital was provided mainly through the Advances to Settlers Act, the design and implementation of which, and public commentary about, displayed the tension inherent in responses to drought that we still see today. While its intended aim was a "hand-up" for longer term development, its implementation was often in the form of a "handout" for short term relief.

The Advances to Settlers Act 1899 was enacted in a period of drought and it specifically acknowledged the "necessitous circumstances" and financial embarrassment that farmers were then experiencing. Financial reports in the New South Wales Year Books show that advances were made, and repaid, under this Act almost continuously to 1981 and the spikes in the number and amount of loans correspond to drought periods in 1903, 1914, 1922, 1930 and 1972. While the 1899 Act clearly indicated that it was targeted at those in "necessitous circumstances" the practical distribution of funds revealed ambivalence about its purpose. In 1902, the Sydney Morning Herald reported that the secretary of the Advances to Settlers Board wrote to the Premier of New South Wales informing him that "the board is in no position to afford assistance purely as a matter of relief" adding that "all transactions under the act can be regarded as of a business character". 33

Newspapers throughout the country had followed the implementation of the Advances to Settlers Act in New Zealand in 1894 with some interest and many noted the value of introducing a similar scheme in Australia. During the first five years of the Advances to Settlers Act in New South Wales, newspapers provided almost daily updates of the amounts paid out by the administrating board as well as extensive coverage of the legislative process regarding the Act. They also informed farmers how to apply for and receive the relief it offered. Not all commentators, however, saw the availability of easy loans for struggling farmers in a positive light, with one newspaper editorial noting that it presented "a temptation which probably few will have the moral courage to resist". ${ }^{44}$ Farmers themselves appear to have recognised the tension in receiving "relief" as opposed to a transaction of a "business character". The Farmers and Settlers Association of NSW at their annual conference in 1899, for example, called upon the government to take a more "humane consideration" in assisting distressed farmers. While placing the onus of responsibility for assistance on the government, however, conference speakers also acknowledged the responsibility of the Association in ensuring that its members were active in returning government advances. ${ }^{35}$

\footnotetext{
32 NSWYB 1925-26, p.772.

33 "Relief for Sufferers", Sydney Morning Herald, 8 February 1902, p.10.

34 Mercury, 1 February 1895, p.2.

35 Albury Banner and Wodonga Express, 25 August 1899, p.34.
} 
Public concerns regarding the administration of the Advances to Settlers Act were articulated in the letters to the editor section of newspapers. A number of letters submitted to the Sydney Stock and Station Journal, the self-proclaimed "organ of the men on the land", expressed concern over the inadequacies of the Act in 1903. One correspondent, writing under the name "Drought Victim", called for an expansion of the Act to include all settlers enduring hardship not just those covered by the legislation. ${ }^{36}$ Another was critical of what they described as the "paltry" sums of money received by farmers, deeming them insufficient to cover even their most basic requirements. ${ }^{37} \mathrm{~A}$ letter, published under the title "A fair deal wanted", bemoaned the inefficiency and delay in the distribution of funds by the board. ${ }^{38}$

Early twentieth-century coverage of the Advances to Settlers Act in both metropolitan and provincial newspapers was broad and comprehensive. There was a general acknowledgment that the drought relief provided by the Act was, for the most part, an effective mechanism for assisting farmers in distress but then, as now, they did not hesitate to publish criticism of the perceived flaws in the intent and implementation of the Act. That assistance was too little, too late, of not the right kind, inaccessible to others who needed it, or given on unrealistic terms, are criticisms that have also been made in the media about the 2014 government package. ${ }^{39}$ The contradictory public reactions to government response to drought during the Federation drought - whether this response should be "relief" or a "business transaction" - is remarkably similar to questions about the 2014 response - whether it should contain "handouts" or a "hand-ups".

\section{4-15 drought}

Similarly contradictory reactions were displayed by newspapers during the 1914-15 drought in the Mallee region. Commentary at this time also displayed an attitude that has since been labelled "countrymindedness". This idea posited a special status for those living in rural areas and was often framed in a manner which exalted rural values against the perceived selfishness and greed of the cities. ${ }^{40}$ This country/city divide inserts another level of complexity into debates around the nature of drought and appropriate government responses to the distress that it causes. It is, however, a binary that is no more solid than the difference between a "handout" and a "hand-

\footnotetext{
36 "The Advances to Settlers Act", Sydney Stock and Station Journal, 6 January 1903, p.10.

37 "Advances to Settlers Board", Sydney Stock and Station Journal, 17 April 1903, p.4.

38 "A Fair Deal Wanted", Sydney Stock and Station Journal, 15 May 1903, p.7.

39 "Drought Package Welcomed, But 'Not Enough Cash", ABC Rural, 26 February 2014

< bttp:/ / www.abc.net.au/news/2014-02-26/farmers-drought-package/ 5282228>; "Drought-stricken Queensland Farmers Still Waiting for Promised Federal Relief', Guardian, 30 April 2014

<http:/ / www.theguardian.com/ environment/2014/apr/30/drought-stricken-queensland-farmers-still-waiting-for-promised-federalrelief $>$.

40 R.B. Walker, The Newspaper Press in New South Wales, 1803-1920 (Sydney, 1976), p.176.; Brad West and Philip L. Smith, "Drought, Discourse, and Durkheim: A Research Note", Australian and New Zealand Journal of Sociology, Vol. 32, 1 (1996), pp.95-96; Don Aitken, “Countrymindedness: The Spread of an Idea” Australian Cultural History, No. 4 (1985), pp.34-41.
} 
up". It did not, for example, appear to determine individual farmers' responses to government assistance. This section will examine, more closely, popular and individual farmers' responses to government drought relief.

Provincial newspapers advocated for farmers, urging the government to provide prompt and adequate drought relief measures. The measures suggested by the Swan Hill Guardian included cash advances to be made for the improvement of land, the provision of relief work to those most in need, the remission of unpaid water rates and stricter control of the price of fodder to prevent profiteering on the part of suppliers. ${ }^{41}$ The Warracknabeal Herald recognised that many farmers in distress considered it the duty of government to come to their assistance, suggesting the provision of seed wheat, the facilitated agistment of stock and an extension of repayment terms on government loans among its proposals for relief. ${ }^{42}$ As outlined above, these measures were already part of government response to drought and both newspapers declared that they had been successfully put in place during the disastrous drought of 1902.

Reports in the provincial newspapers to the government's response measures recognised both the efforts and difficulty associated with the provision of relief to stricken farmers. The Quambatook Times praised the government for their assistance and expressed general satisfaction with the manner in which the Relief Board dealt with settlers. ${ }^{43}$ The Swan Hill Guardian also congratulated the government for recognising the urgency of the situation and dealing with it in a prompt and businesslike manner. ${ }^{44}$ But not all newspapers in the Mallee were so kindly disposed to the government's efforts. An editorial entitled "Government Ineptitude", in the Mildura Cultivator in 1915, was severely critical of government endeavours to provide assistance to distressed farmers. The editorialist reproached the Mallee Relief Board for the belated and insufficient relief it administered and scoffed at the idea that the Board having to deal with "2500 letters in nine weeks" was "strenuous" work. ${ }^{45}$ Similar sentiments were expressed by the local newspaper in the nearby town of Pinnaroo, South Australia where it was felt that government promises relating to the provision of relief had fallen short of expectations. ${ }^{46}$

Metropolitan newspaper reports added their voice to attacks on the government but also criticised farmers. In 1914, for example, the Melbourne Leader claimed that all of the government's good intentions were being undermined by red tape and "stupidities in administration". ${ }^{47}$ It pursued its campaign against bureaucratic inefficiency and, five months later,

\footnotetext{
41 "Distressed Farmers", Swan Hill Guardian and Lake Boga Advocate, 13 May 1915, p.3.

42 “The Dry Season: Relief Measures Sought”, Warracknabeal Herald, 9 October 1914, p.3.

${ }^{43}$ Quambatook Times, 2 June 1915, p.3.

44 "Distressed Farmers", Swan Hill Guardian and Lake Boga Advocate, 13 May 1915, p.3.

45 "Government Ineptitude", The Mildura Cultivator, 3 February 1915, p.7.

46 Warracknabeal Herald, 22 January 1915, p.6.

47 “The Week", Leader, 21 November 1914, p.35.
} 
added that the need for such relief was urgent. ${ }^{48}$ A 1916 report in the Independent on a Farmer's Conference in Warrnambool, however, bemoaned farmers' lack of foresight. While the commentator acknowledged that this drought was a "hideous nightmare" and recognised the uncertainty and inevitability of drought, they felt that more could be done to lessen its impact. ${ }^{49}$

Rural and regional newspapers reported drought relief differently to metropolitan newspapers.

As R. B. Walker has noted, provincial papers vigorously promoted the issues that most concerned the town or district which they covered, as well as the material and social advancement of their readers. ${ }^{50}$ These newspapers were an "integral part of the make-up of the community ... and a mirror of its local life". ${ }^{51}$ Their reports displayed that feature of "countrymindedness" that lauded rural work, summed up in a 1914 article in the Swan Hill Guardian that claimed the Mallee farmers as the "backbone of the State" of Victoria.52 Newspapers reported on the "admirable spirit" of settlers despite their distress ${ }^{53}$ and their cheerfulness in the face of a "disastrous season". ${ }^{44}$ But claims that farmers were self-reliant and uncomplaining sat uneasily with reports of their urgent needs and questions about their lack of foresight.

The portrayal of farmers as "not given to make outcries about their conditions" 55 may have helped avoid any stigma attached to receiving relief but more personal reactions to government assistance show that we cannot make generalisations about the type of assistance needed in individual circumstances, nor how that assistance was perceived.

William Pearse had been farming in the Mallee only two years when the Federation drought began. The drought struck particularly fiercely in the Victoria Mallee with rainfall less than one third of the annual average and Pearse's wheat harvest, like many in south eastern Australia failed completely in 1896. "Crops are about cooked. It has been awful weather" he remarked in October. ${ }^{56} \mathrm{He}$ successfully applied for financial assistance under the Seed Advances Act to buy seed for 100 acres. ${ }^{57}$ Harvests continued to be erratic, Pearse had again gone into debt and nine of his horses died. Pearse began 1902 optimistically sowing 245 acres of wheat, however, like many farmers in the south eastern Australian wheat belt, he again harvested nothing and had no seed to sow the following autumn. Having no crop to harvest William worked for his father, shearing and droving.

48 “The Week", Leader, 10 April 1915, p.34.

49 "Hitting Them Up", The Independent, 28 July 1916, p.3.

50 Walker, The Newspaper Press in New South Wales, 1803-1920, p.176.

51 E.C. Sommerlad in Rod Kirkpatrick, "The Mirror of Local Life: Country Newspapers, Country Values and Country Content”, in Communication and Culture in Rural Areas, ed. Perry O’Brien Share (Wagga Wagga, 1995), p.225.

52 "The Drought: A Few Suggestions", Swan Hill Guardian and Lake Boga Advocate, 12 October 1914, p.3.

53 "Farmers \& the Drought", Swan Hill Guardian and Lake Boga Advocate, 4 February 1915, p.4.

54 "Mallee Relief. Attitude of the Board", Ouyen Mail and Central Mallee Advertiser, 16 April 1915, p.2.

55 "Relief for Farmers. Discussion in Legislative Council", Swan Hill Guardian and Lake Boga Advocate, 1 October 1914, p.6.

56 Pearse, Diaries 1893-1947, State Library of Victoria (SLV), MS 12961, 17 October 1896.

57 Pearse, 13 March 1896. 
April 1903 is considered the end of the Federation drought but despite adequate rainfall, this was Pearse's most difficult year. In January 1903 Pearse again applied for a $£_{40}$ government advance on fodder and seed. ${ }^{58}$ As many farmers had also received subsidies and little fodder was available in the district, feed prices were inflated so did not cover all his fodder needs. ${ }^{59}$ Pearse sowed wheat and oats in autumn 1903, 250 acres with government seed and a further 120 acres on half shares with his father. "Pa" provided seed and horse feed and William provided labour but it would be another year before he received an income from this harvest. The accumulation of poor harvests throughout much of the Federation drought meant that expenses far outweighed his income. The family's expenditure for 1903 was $£ 127$ but income was just over $£ 3$. His father wrote off outstanding debts and for two months when the family had no income and few other means of support Pearse's parents provided board, work and a small wage. When Pearse completed his budgets he did not include the government advances, probably because it was repayable so he did not consider it income. Six good harvests followed the long Federation drought and Pearse repaid his $£ 40$ advance. When the next severe drought afflicted south-eastern Australia in 1914 he had no debt. Despite another failed harvest at the end of 1914 he did not apply for government advances and was able to procure and sustain the cost of agistment. As a Methodist lay preacher, Pearse had extensive social networks and was able to secure scarce agistment for six cows and ten horses. Rail transport for the horses was probably subsidised by the government with the cost of this agistment again paid by his father. ${ }^{60}$

Government assistance was important in helping Pearse to sow wheat and feed his horses during the Federation and 1914 droughts, however it was just one financial measure among others which sustained him. Support from Pearse's parents was the more crucial difference between continuing to farm and going under. Pearse's story illustrates that drought crisis relief was important to some farmers, although was not always the most important factor in drought endurance. Pearse's story also shows how even a self-reliant and resourceful farmer relied on a combination of family, community and government to endure repetitive droughts. Pearse himself did not reflect on receiving government drought assistance in his diary so we do not know what significance he placed on government assistance.

For the Cornell family, however, we have explicit acknowledgment of the role that short-term relief and long-term investment from the government played in their survival. Mary Olive Cornell, a young woman of 24, and her family settled on nearly 2000 acres near Murrayville, a few years before the 1914 drought. There was no surface water in that part of the Mallee and farmers relied on carting water from a government bore for their stock and household. 1914 was particularly dry and the Cornell family, and most of their neighbours, harvested nothing that year:

\footnotetext{
58 Pearse, 24 February 1903.

59 "The Grain Trade", Australasian, 14 February 1903, p.11.

${ }^{60}$ Pearse, 4-6 November 1914.
} 
"no stripping - no winnowing - no bag sewing and no carting". Mary recalled that year as very quiet: "no hum of voices calling to the teams, no buzzing of the reaper and winnower and no dust from the teams along the road, no life whatever, peaceful perhaps but most strange. There was nothing to put back and there was a year to [be] gone through somehow". ${ }^{61}$

This part of the Mallee was particularly vulnerable to drought in 1914 as it was newly settled and most farmers had been unable to build up reserves of fodder, water and finance. Mary recalled that settlers were able to access government food sustenance, paid according to the size of the family, but was proud that the Cornell family did not need this: that year their diet consisted of flour, rabbits, dripping and paddy melon weeds for fruit pies. The Cornell family did, however, receive financial assistance from the government to buy seed wheat and fertiliser. In addition to this immediate financial assistance the Cornells also received structural assistance to make their new farm viable. This assistance allowed them to sink a bore to provide palatable water for the house and farm rather than carting water from a public bore some distance from the farm. Murrayville lies in the relatively small area of the Victorian Mallee - a strip of about 1820 square kilometres east of the South Australian border - which has access to fresh ground water. ${ }^{62}$ Digging the bore to a depth of 300 metres and constructing a windmill to pump the water to the surface took two months. By the end of 1915 the Victorian government had sunk 79 bores in this area which supplied about 2500 people in townships and on farms. ${ }^{63}$

Seventy years later, when writing a memoir of the 1914 drought years, Mary Cornell reflected: "Dreadful as it was - the farmer - although enduring hardships for the time being, was not altogether on the debit side. There were many improvements made to his farm through the assistance of the Gov't., which he might have gone for years without and which, of course, added materially to the value of his farm". This windmill on the Cornell farm remained an enduring symbol of government assistance in the midst of drought: "We always called our windmill 'A Monument to Drought"'. ${ }^{64}$ The 1914-15 drought may have found the Cornell family unable to look after themselves but government assistance in the form of both handout and hand-up provided for their distress and helped them on the way to self-reliance.

\section{Foresight and self-reliance}

"Self-reliance" was a key term in the 1992 National Drought Policy, ostensibly part of the neoliberal ideology of independence and "looking after yourself" which has dominated economic policy since the 1980s. Yet the idea that farmers should be self-reliant runs through the long

\footnotetext{
${ }^{61}$ M.O. Cornell, "Drought in the Mallee 1914", SLV, MS8793, p.1.

${ }^{62}$ L.R. East, $W$ ater in the Mallee (Melbourne, 1965), p.185.

${ }^{63}$ Jenny Keating, The Drought Walked Through: A History of Water Shortage in Victoria (Melbourne, 1992), p.87.

${ }^{64}$ Cornell, "Drought in the Mallee 1914", p.2.
} 
history of drought response in Australia. The 1920s Rural Credit and Community Settlement Scheme was one example of a government initiative to lessen future government involvement in rural development. Established in 1923 on the recommendation of a Select Committee of the Legislative Council inquiry into the condition of the agricultural industry as "an efficient system of rural credit on co-operative principles" with the aim of "stimulating local development through community settlement" the Scheme was promoted through a series of educational conferences in country districts. By 1926, 76 rural co-operative societies had been registered. ${ }^{65}$ Cash advances to needy farmers at this time were made only in exceptional circumstances and were more likely to be given when they "encourage[d] better farming methods" ${ }^{66}$

That self-reliance is a factor in drought policy reflects wider social ideals evident since colonisation. Economic and social independence was an inherent part of settler society and the search for individual independence through land was a strong motivation for emigration of free settlers to Australia and for the spread of settlement within the colonies. Rural settlers brought with them an enduring myth in the English speaking world: the yeoman ideal of the farmer who was neither owned by, nor accountable to, a master - a man who was king of his own domain and free of external control. Self-reliance and a disinclination to request assistance were, therefore, an inherent part of colonial identity. ${ }^{67}$

Other key features of the 1992 Policy - risk management, productivity growth and structural adjustment - can also be seen throughout the first six decades of the twentieth century in the small but continuous and consistent example of the reporting of ensilage rates. In the 1909 Commonwealth Year Book, ensilage is described as "the judicious economising of the surplus growth of green food" - that is, risk management - which turns "weeds of all sorts" into "succulent and nutritious food" so that "farmers and squatters can carry more stock on their holdings than they otherwise would be justified in doing" - that is, productivity growth. Silos built of hardwood or concrete that replaced pit and stack silos prone to mould and fire risk, and portable scalable silos made of iron, encouraged further productivity growth. ${ }^{68}$ Structural adjustment can be seen in the Victorian government's "Assistance in the Production of Ensilage" which included education, expert supervision of the erection of silos and favourable loans for such work. Similarly, in 1914 the New South Wales Government was trying to educate farmers on the value of ensilage by giving advice in the "Agricultural Gazette", issuing special bulletins and erecting silos on experimental farms. ${ }^{69}$ In 1934 "various State Governments" were devoting

\footnotetext{
65 NSWYB 1925-26, pp.773-74.

${ }^{66}$ NSWYB 1927-28, p.706.

${ }^{67}$ R.J. Short, Imagined Country: Environment, Culture and Society (London, 1991), pp.28-33 particularly;

R. Williams, The Country and the City (Oxford, 1973).

${ }^{68}$ CYB 1909, pp.424-25.

${ }^{69}$ CYB 1914, p.355.
} 
"a considerable amount of attention to the education of the farming community in regard to the value of ensilage" through both "[m]onetary aid" and "expert advice". ${ }^{70}$

The commentary accompanying ensilage statistics praised increases and censured decreases. The 1903 Victorian Year Book expressed surprise that after 20 years of testing in America, so little had been done in Australia. ${ }^{71}$ The 1913 New South Wales Year Book noted that quantities of ensilage were "almost negligible in the districts that needed it most". ${ }^{72}$ The Commonwealth Year Book in 1914 acknowledged the value of ensilage during the drought but felt that more could have been done during the previous years of surplus growth. ${ }^{73}$ By 1926-27 the commentary on ensilage was less equivocal: "Considering the liability of the State to periods of severe drought, the small efforts made to conserve the fodder of abundant seasons are disappointing". ${ }^{74}$ Ensilage rates were reported continuously in the Commonwealth Year Books until 1959. But in 1967, the Minister for Primary Industry, Charles Adermann was still wondering in parliament what assistance or scheme would "enable producers to conserve fodder on their own properties for use when they become the victims of drought?". ${ }^{75}$

Charles William Coote was one farmer who depended on himself and expected his neighbours to do the same. Coote selected land in the Victorian Mallee in the early 1890s and farmed there until the early 1950s, but, unlike William Pearse and the Cornell family, Coote eschewed direct government drought relief. Although Coote's wheat harvest failed in the 1902-3 season, he did not apply for government seed or fodder advances and he did not agist his horses although, (for a small fee) he escorted a neighbour's six horses to southern districts for agistment. Without any income from farm produce Coote took State and local government work cleaning water channels, which he described contemptuously as "shovelling muck" and "slinging mud". ${ }^{76}$ In the latter years of the Federation drought he also took local government contracts clearing roads for which he was paid $£, 50$ for eight weeks' work.

Although Charles Coote did not receive direct financial assistance from the government he believed strongly in the role of governments in creating infrastructure to assist farmers. He campaigned for construction of roads and reservoirs and the reduction of railway freight charges. He was also a tireless agitator for the construction of the Mallee-Wimmera stock and domestic water supply. He organised petitions, community meetings, attended delegations to Melbourne and enticed Members of Parliament and to attend meetings in local towns until the mid-1930s when water channels to the district were laid. By the end of the First World War Coote was an

${ }^{70}$ CYB 1934, p.606.

${ }^{71}$ VYB 1903, p.408-409.

72 NSWYB 1913, p.798.

${ }_{73}$ CYB 1915, p.356.

${ }^{74}$ NSWYB 1926-27, p.682.

75 House of Representatives Official Hansard, Thursday, 9 March 1967, p.496.

${ }^{76}$ Charles William Coote, Records of Charles William Coote 1896-1955, 6 and 11 May 1903, University of Melbourne Archives, 1964.0005 . 
established and fairly wealthy farmer with nearly 1900 acres. In the 1920s and 1930s when many soldier settlers in the Mallee were struggling because of drought, low prices for farm products and small and unsuitable blocks, Coote continued his campaigns on their behalf forming a delegation to the Shire council to advocate for employment clearing roads or water channels.

Coote, however, strongly condemned farmers who received drought relief payments and longterm credit. Uncleared debt and government welfare was a source of great irritation to Coote, compounded by the fact that as well as a farmer he was a director of the local agricultural cooperative store which, by 1929, had debts of over $£^{2} 800$ from new settlers. In his diaries he decried farmers" priorities. In January 1930 he wrote: “Tennis courts in park kept busy all day some coming in motor cars to play and many cannot pay for the food they ate last year. Drought and bad season blamed for that; no idea apparently of meeting deficiency by self-denial in any way". ${ }^{77}$ In March 1934 he criticised the government tendency to keep "needy and some cases unfinancial farmers on the land"78 and in February 1935 he expressed disbelief that farmers rely on assistance rather than their own abilities: "holiday for many whether they can afford it or not. Very little effort made so far to pay accounts ... The majority seem to think they should not be expected to pay old debts. Generally it seems as though people have not faced their difficulties of the past five years as those of forty years ago would have done - relied upon themselves". 79 Although Coote also expressed compassion for people in need - he lent tools, horses and money to neighbours and relatives and donated to charity - he condemned government assistance in the form of financial payments and credit and believed that farmers had a duty to provide for themselves.

Coote's feelings about the self-reliance of farmers and government responsibility to support only those farmers who demonstrated it was reflected in the establishment of the Rural Reconstruction Board back in 1939 and postwar reconstruction after the Second World War as the Board's "main function" made clear: "to assist in restoring to a sound basis for farmers in financial difficulties who [were] deemed to have reasonable prospects of carrying on". 80 As Tom Griffiths has noted, postwar reconstruction revisited progressivist ideas of continual economic expansion which had driven agricultural settlement in the nineteenth century ${ }^{81}$ but the success of reconstruction - and its subsequent incarnation as "structural adjustment" - needed the selfreliance and ongoing work of farmers themselves. So the Commonwealth Development Bank, which began operations in 1960, was required to look at a prospective borrower's chances of success rather than the amount of security that could be provided ${ }^{22}$ and the Rural Reconstruction

\footnotetext{
77 Ibid., 19 January 1930.

78 Ibid., 11 March 1934.

${ }^{79}$ Ibid., 10 February 1935.

80 NSWYB 1950-51, p.707.

${ }^{81}$ Griffiths, "One Hundred Years of Environmental Crisis", pp.5-14.

${ }^{82}$ NSWYB 1961, pp.228-29.
} 
Scheme of the 1970s aimed to "help restore to economic viability those farms and farmers with capacity to maintain viability in the longer term". Assistance included debt restructuring, loans for small proprietors to acquire additional lands in order to be of an economic size, and loans and retraining for farmers leaving agriculture. ${ }^{83}$ In the 1980s, when drought was explicitly covered by natural disaster relief payments, credit continued to be extended to agriculturalists on more favourable terms than for other industries to refinance long-term expenditure as part of "recovery from natural disasters". Even commercial trading banks had farm development loan facilities to cover loans for measures for both recovery from drought and the mitigation of the effect of future droughts. 84

\section{Conclusion}

Australian governments have provided government assistance, in various forms, to farmers since European settlement. As early as March 1796 three settlers affected by an ice storm that destroyed their almost ripe wheat crop were acknowledged by Governor Hunter as needing some aid from government to recover. ${ }^{85}$ Colonial administrators, however, were as conflicted as our current politicians about how to act. Hunter thought farmers careless in 1797 when they lost their harvests to bushfires but in 1799 felt compelled to grant settlers' applications for seed wheat following drought and flood destruction - he could not allow the scarcity of grain to continue. ${ }^{86}$ When faced with similar shortages in 1839, Governor George Gipps removed duty and wharfage from grain and flour imports though he was, he wrote, "disinclined on general principles to interfere in such matters", ${ }^{87}$ Reactions to government assistance during the nineteenth century ranged as widely as they did in the twentieth. In 1841 Scottish Highland emigrants defended themselves with recourse to drought, flood, low prices and debt against John Dunmore Lang's accusation that their lack of success was due to their "indolence and mismanagement". ${ }^{88} \mathrm{~A} \mathrm{Mr}$ Chisholm of Camden conceded at a public meeting in 1864 that the State should not intervene in every instance but that there were special occasions when "the interposition of the State was necessary". ${ }^{99}$ And a "large and influential meeting of squatters" in Dubbo in 1869 called for changes to land laws that would assist them gain access to credit in hard times such as drought.90

What might we learn from this longer history of government drought assistance and the public and personal responses to it? Many commentators emphasise that it is our lack of understanding

\footnotetext{
${ }^{83}$ CYB 1972, p.551, p.743.

${ }^{84}$ NSWYB 1982, pp.421-22.

${ }^{85}$ Hunter to Portland, 3 March 1796, Historical Records of Australia (HRA), Series 1, Vol. 1, p.554.

${ }^{86}$ Hunter to Portland, 10 June 1797, HRA, Series 1, Vol. 2, p.20; Hunter to Portland, 1 May 1799, HRA, Series 1, Vol.

2 , p.355.

${ }^{87}$ Gipps to Glenelg, 8 April 1839, HRA, Series 1, Vol. 20, p.108.

88 Sydney Herald, 30 August 1841, p.3.

${ }^{89}$ Empire, 12 April 1864, p.5.

90 Sydney Morning Herald, 18 May 1869, p.3.
} 
of drought, and of drought in the Australian environment, that accounts for inconsistent and ineffective drought responses. Some have argued that the continued existence of government drought assistance actually reinforces the idea that drought is an aberration rather than a natural part of the Australian climate. ${ }^{91}$ Our study of drought assistance over nearly 150 years, however, is leading us to the conclusion that government initiatives, and the popular and personal responses to those measures, are not neatly aligned with the dichotomous perception of drought as either a natural disaster or an inherent part of the Australian climate which the rhetoric of handouts versus hand-ups reinforces. There has always been, within government, popular commentary and among farmers themselves, some acknowledgement that drought is an expected part of farming and that, in the perceived tradition of our pioneering settlers, farmers should display self-reliance rather than rely on government assistance. At the same time, there has also been recognition that farmers are not discrete economic units and that not only their families, but their communities and our wider society share their distress - and whether that distress was beyond their control or not, at some point, we are bound to at least try to alleviate the suffering.

A consistent pattern of variable, sometimes contradictory and never fully effective, approaches to drought has been evident across government legislation, media commentary and farmers' personal responses since at least the late nineteenth century. It may be that we need to consider that what has hindered effective government response to drought is not so much a lack of understanding of drought. Rather it is the unchanging combination of emotionally charged rhetoric, personal philosophies, political expediencies and unevenly informed public opinion on which this response is based that creates an apparent tension between handouts and hand-ups. This complex mix of factors is beyond the scope of this preliminary study to explore but it does show the value of further research that takes account of the ideological, psychological, cultural and historical facets of drought. We will also need to consider that increasing frequency and intensity of drought in the future is only going to make the status quo even less effective and the debates around drought assistance more shrill and more intense.

${ }^{11}$ Dan Daly, Wet as a Shag, Dry as a Bone: Drought in a Variable Climate (Brisbane, 1994), p.93. 